\title{
Internalisasi Nilai-Nilai Pendidikan Kewirausahaan Dalam Kurikulum di SMK Salafiyah Syafi'iyah Randangan Provinsi Gorontalo
}

\author{
Nurhamida \\ Nurhamidapattiwi77@gmail.com
}

\begin{abstract}
ABSTRAK
Penelitian ini adalah penelitian lapangan dengan menggunakan jenis penelitian deskriptif kualitatif, dengan pengambilan sampel sumber data secara purposive sampling. lokasi penelitian pada SMK Salafiyah Syafi'iyah Randangan Gorontalo. Sumber data penelitian yaitu primer dan sekunder yaitu data primer bersumber dari informan di lapangan melalui wawancara dan observasi partisipasi serta foto-foto dan data sekunder berupa dokumen berupa buku-buku dan literature yang relevan yang dituliskan dalam catatan lapangan. Teknik analisis data yang digunakan dalam penelitian ini adalah reduksi data (reduction) yang dilakukan dengan jalan melakukan abstraksi, penyajian data (display), penarikan kesimpulan (conclution/verification). Pengujian keabsahan data dilakukan dengan pengamatan, memperpanjang kehadiran peneliti, triangulasi dan diskusi dengan teman sejawat.

Temuan hasil penelitian menunjukan bahwa (1) Internalisasi nilai-nilai pendidikan kewirausahaan pada mata pelajaran sudah diterapkan yaitu dimasukkannya nilai-nilai tersebut ke dalam perencanaan pembelajaran seperti silabus dan RPP, walaupun dalam pelaksanaan pembelajaran dengan segala keterbatasan guru yang tidak berlatar belakang pendidikan sesuai dengan mata pelajaran yang di ampuhnya, dan telah telihat perubahan sikap peserta didik di dalam pembelajaran dari penanaman lima nilai kewirausahaan seperti kreatif dan mandiri, namun dalam hal evaluasi pembelajaran belum mengacu pada standar penilian yang baku.(2).Faktor pendukung internalisasi nilai pendidikan kewirausahaan yaitu semangat belajar yang tinggi dari peserta didik, ruang belajar yang nyaman, metode pembelajaran yang tepat, media atau lat belajar yang lengkap dan berfungsi baik, serta keteladanan dari guru atau komponen sekolah, sedangkan faktor penghambat yaitu keterlambatan peserta didik di ruang belajar, guru yang tidak sesuai dengan latar belakang pendidikan, tingkat pemahaman peserta didik yang berbeda-beda, ketersediaan sarana dan prasarana yang masih minim di SMK Salafiyah Syafi'iyah Randangan rendahnya kualitas sumber daya manusia, sarana prasaran pendukung praktik peserta didik belum memadai, serta faktor modal yang sangat minim serta keterbatasan modal untuk mendukung praktik peserta didik.
\end{abstract}

Keywords: Internalisasi Nilai Pendidikan, Kewirausahaan, Kurikulum Di SMK 


\section{BAB I \\ PENDAHULUAN}

A. Latar Belakang

Pendidikan kewirausahaan di sekolah mulai tahun 2010 telah disosialisasikan oleh Kementerian Pendidikan Nasional di pendidikan dasar dan pendidikan menengah didasarkan pada butir-butir kebijakan nasional yang tertuang dalam RPJMN 2010 - 2014 yaitu peningkatan akses pendidikan yang berkualitas, terjangkau, relevan, dan efisien menuju terangkatnya kesejahteraan hidup rakyat, kemandirian, keluhuran budi pekerti, dan karakter bangsa yang kuat. Pembangunan bidang pendidikan diarahkan demi tercapainya pertumbuhan ekonomi yang didukung keselarasan antara ketersediaan tenaga terdidik dengan kemampuan: 1) menciptakan lapangan kerja atau kewirausahaan, 2) menjawab tantangan kebutuhan tenaga kerja. b). Penataan ulang kurikulum sekolah yang dibagi menjadi kurikulum tingkat nasional, daerah, dan sekolah sehingga dapat mendorong penciptaan hasil didik yang mampu menjawab keutuhan SDM untuk mendukung pertumbuhan nasional dan daerah dengan memasukkan pendidikan kewirausahaan, seperti yang terjadi Di SMK Salafiyah Syafi'iyah Randangan di mana kurikulumnya memasukkan pendidikan kewirausahaan sebagai mata pelajaran wajib dan melakukan penambahan jam di luar waktu pembelajaran yaitu di sore hari.

Pendidikan kewirausahaan merupakan aspek penting bagi perkembangan sumber daya manusia, sebab pendidikan kewirausahaan merupakan wahana atau salah satu instrumen yang digunakan bukan saja untuk membebaskan manusia dari keterbelakangan, melainkan juga dari kebodohan dan kemiskinan. Disisi lain, pendidikan kewirausahaan dipercayai sebagai wahana perluasan akses dan mobilitas sosial dalam masyarakat baik secara horizontal maupun vertikal.

Semakin maju suatu negara semakin banyak orang yang terdidik, dan banyak pula oarng yang menganggur, maka semakin dirasakan pentingnya dunia kewirausahaan pembangunan akan lebih berhasil jika ditunjang oleh entrepreneur yang dapat membuka lapangan kerja karena kemanpuan pemerintah sangat terbatas. 
Pemerintah tidak akan mampu menggarap semua aspek pembangunan karena sangat banyak membutuhkan anggaran belanja, persoanalia, dan pengawasan. ${ }^{1}$

Selanjutnya menurut UU No 20 Tahun 2003 tentang Sisdiknas, pasal 37, menyatakan bahwa kurikulum SMK wajib memuat tentang Pendidikan Agama, Pendidikan kewarganegaraan, Bahasa, Matematika, Ilmu Pengetahuan Alam, Ilmu Pengetahuan Sosial, Seni dan budaya, Pendidikan jasmasi dan olah raga, Keterampilan/kejuruan, dan Muatan lokal. Atas dasar itu, maka mata pelajaran wajib pada KTSP SMK terdiri atas Pendidikan Agama, Pendidikan Kewarganegaraan, Bahasa, Matematika, IPA, IPS, Seni dan Budaya, Pendidikan Jasmani Olahraga dan Kesehatan, dan Keterampilan/Kejuruan (terdiri atas Keterampilan Komputer dan Pengelolaan Informasi dan Kewirausahaan).

Kurikulum tingkat satuan pendidikan tahun 2006 menekankan bahwa satuansatuan pendidikan harus mampu mengembangkan komponen-komponen dalam kurikulum tingkat satuan pendidikan. Komponen yang dimaksud mencakup visi, misi, dan tujuan tingkat satuan pendidikan; struktur dan muatan; kalender pendidikan; silabus sampai pada rencana pelaksanaan pembelajaran.

. Dalam kurikulum di SMK Salafiyah syafi'iyah Randangan terdapat mata pelajaran kewirausahaan yang memang dirancang untuk memberikan pengetahuan tentang kewirausahaan kepada siswa. Adapun materi pelajaran kewirausahaan yang diberikan telah mencakup karakter kewirausahaan yang terkandung di dalamnya. Oleh karena itu sangat penting untuk mengembangkan Kurikulum Pendidikan Kewirausahaan agar mampu mencetak wirausaha-wirausaha baru yang handal. Hal ini tentu saja tidak menjadi tanggung jawab pemerintah semata, atau guru semata namun manjadi tanggung jawab bagi semua pihak yang terkait di dalamnya termasuk juga stakeholder/masyarakat.

\section{Kajian Pustaka}

Penelitian terdahulu menjadi salah satu acuan penulis dalam melakukan penelitian sehingga penulis dapat memperkaya teori yang digunakan dalam mengkaji penelitian yang dilakukan. Dari penelitian terdahulu, penulis tidak menemukan penelitian dengan judul yang sama seperti judul penelitian penulis.

\footnotetext{
${ }^{1}$ Buchari Alma ,Entrepreneurship, (Bandung : Alfabeta , 2013), hlm. 1
} 
Namun penulis mengangkat beberapa penelitian sebagai referensi dalam memperkaya bahan kajian pada penelitian penulis. Berikut merupakan penelitian terdahulu berupa beberapa tesis dan jurnal terkait dengan penelitian yang dilakukan penulis sebagai berikut:

1. Endang Mulyani, judul penelitiannya tentang Model Pendidikan Kewirausahaan di Pendidikan Dasar dan Menengah. Hasil analisis menunjukan bahwa Keberhasilan pendidikan kewirausahaan dapat diketahui melalui pencapaian kriteria oleh peserta didik, guru, dan kepala sekolah yang antara lain meliputi: peserta didik memiliki karakter dan perilaku wirausaha yang tinggi, lingkungan kelas yang mampu mengebangkan kebiasaan dan perilaku peserta didik yang sesuai dengan nilai-nilai kewirausahaan yang dIntegrasikan, serta lingkungan kehidupan sekolah sebagai lingkungan belajar yang bernuansa kewirausahaan. ${ }^{2}$

Perbedaan penelitian yang dilakukan oleh Endang Mulyani yang membahas tentang Model Pendidikan Kewirausahaan di Pendidikan Dasar dan Menengah, sedangkan penelitian yang dilakukan oleh penulis adalah Integrasi Nilai-nilai pendidikan kewirausahaan dalam kurikulum di SMK Salafiyah Syafi'iyah Randangan gorontalo yang mengacu pada Kemendiknas tahun 2010

2. Husaini Usman dan Nuryadin Eko Raharjo, Model Pendidikan Karakter Kewirausahaan di Sekolah Menengah Kejuruan. Hasil penelitian ini menunjukkan bahwa model pendidikan karakter kewirausahaan yang telah dilaksanakan di SMKN 2 Depok Sleman menggunakan pendekatan keteladanan,pembelajaran di kelas dan luar kelas,pembudayaan melalui kultur sekolah, dan penguatan .Model pendidkan karakter kewirausahaan yang perlu dikembangkan di SMKN 2 Depok Sleman adalah model pendidikan karakter kewirausahaan yang terintegrasi antara pendidikan karakter dengan pendidikan kewirausahaan.integrasi tersebut dilakukan dengan mengakomodasi intervensi: cultural,structural, dan figur. Pelaksanaan model pendidikan tersebut mencakup: (a). proses pembelajaran di kelas (b) kegiatan kurikuler dan ekstra kurikuler (c)

\footnotetext{
${ }^{2}$ Endang Muliani, "Model Pendidikan Entrepreneurship di Pendidikan Dasar dan Menengah", Jurnal Ekonomi dan Pendidikan, vol. 8 Nomor 1, April 2011
} 
pembelajaran melalui ,kultur sekolah, dan (d) pembelajaran melalui kegiatan di rumah/masyarakat. ${ }^{3}$

3. Moerdiyanto, 2012. Perluasan Implementasi Pendidikan Kewirausahaan Model Project Based Learning Bagi Remaja Putus Sekolah Gempa di kabupaten Bantul DIY. Penelitian ini merupakan penelitian tindakan dengan tujuan untuk mengetahui tingkat keberhasilan kepribadian (jiwa) kewirausahaan dan keterampilan usaha yang dimiliki remaja putus sekolah setelah memperoleh pengalaman belajar bisnis riil dengan model project based learning. Populasi dalam penelitian ini adalah semua remaja putus sekolah korban gempa dikecamatan Piyungan, Kecamatan Pleret, dan kecamatan Sewon Kabupaten Bantul DIY.

4. Abdul Hakim (2010) dengan judul penelitiannya Model Pengembangan Kewirausahaan Sekolah Menengah Kejuruan (Smk) Dalam Menciptakan Kemandirian Sekolah SMK di Kota Semarang. Hasil penelitian menunjukkan bahwa rata-rata kualitas pembelajaran kewirausahaan di SMK dipersepsikan baik oleh para siswa, namun dalam prakteknya, beberapa materi kewirausahaan yang diajarkan belum lengkap dan mengena pada sasaran yang diinginkan untuk mencetak wirausaha. Selanjutnya, kebijakan yang diimplementasikan kewirausahaan di SMK juga rata-rata dipersepsikan baik oleh para guru, namun dalam realitasnya banyak SMK belum memiliki rodmap yang jelas tentang pengembangan kewirausahaan di SMK. Jejaring dengan dunia industri yang masih rendah menyebabkan pembelajaran kewirausahaan di sekolah tidak efek tif. Oleh karena itu dalam penelitian ini diusulkan model yang terintegrasi, agar SMK mampu menghasilkan lulusan yang memiliki motivasi dan ketrampilan wirausaha yang tinggi. ${ }^{4}$

5. Agung Winarno, (2015), Model Pendidikan Kewirausahaan Adaptasi Kurikulum 2013 bagi SMK ( Diskripsi Persiapan dan Hambatan Penerapandi Sekolah). Hasil penelitian menunjukkan bahwa tidak terdapat perubahan yang berarti terkait

\footnotetext{
${ }^{3}$ Husaini Usman \& Nuryadin Eko Raharjo, "Model Pendidikan Karakter Entrepreneurship di Sekolah Menengah Kejuruan”Jurnal Pendidikan Teknologi dan Kejuruan,Vol.21 Nomor 2,Oktober 2012

${ }^{4}$ Abdul Hakim,Model Pengembangan Entrepreneurship Sekolah Menengah Kejuruan (SMK) dalam Menciptakan Kemandirian Sekolah”, Jurnal Riptek, Vol.4, Nomor 3, 2010.
} 
dengan penerapan kurikulum 2013, perubahan terjadi pada proses adaptasi para guru untuk memahami kurikulum terutama pada mata pelajaran Prakarya dan Kewirausahaan yang belum secara lengkap memiliki silabus terstandart. Pada umumnya para guru juga masih ragu atas implementasi yang dilakukan berdasarkan tuntunan kurikulum 2013, ini terjadi disebabkan pemahaman Kompetensi Inti baik sikap spiritual dan sosial sebagai pembelajaran tidak langsung untuk mewarnai pembelajaran langsung pada aspek kompetensi pengetahuan perilaku belum terdapat kesepahaman, selain itu hampir semua guru juga belum memiliki Silabus yang memadai termasuk media dan bahan ajarnya. Model yang ditawarkan dalam penelitian ini terkait dengan pengembangan kurikulum dan perangkat pembelajarannya yang terintegrasi dengan sistem menyeluruh pendidikan Kewirausahaan baik menyangkut fungsi kelembagaan (Sekolah) maupun kualifikasi guru.

Perbedaan penelitian yang dilakukan oleh Agung Winarno, (2015), Model Pendidikan Kewirausahaan Adaptasi Kurikulum 2013 bagi SMK ( Deskripsi Persiapan dan Hambatan Penerapan di Sekolah), dengan penelitian penulis adalah Integrasi Nilai-nilai pendidikan kewirausahaan dalam kurikulum di SMK Salafiyah Syafi'iyah Randangan gorontalo demikian pula perbedaan dilihat dari Judul penelitian serta subjek penelitianya.

\section{Kerangka Teori}

\section{Pengertian Pendidikan}

Pendidikan adalah. "Proses pengubahan sikap dan perilaku seseorang atau kelompok orang dalam usaha mendewasakan manusia melalui upaya pengajaran dan pelatihan"5

Istilah Pendidikan, dalam bahasa Inggris "education", berakar dari bahasa Latin "educare", yang dapat diartikan pembimbing berkelanjutan (to lead forth).

\footnotetext{
${ }^{5}$ Fajri, Em Zul, dan Ratu Aprillia Senja., Kamus Lengkap Bahasa Indonesia, ( Yokyakarta:
} Publisher, 2005), hlm. 254 
Jika diperluas, arti etimologis itu mencerminkan keberadaan pendidikan yang berlangsung dari generasi ke generasi sepanjang eksistensi kehidupan manusia ${ }^{6}$

Makna pendidikan secara sederhana dapat diartikan sebagai usaha manusia untuk membina kepribadiannya sesuai dengan nilai-nilai di dalam masyarakat dan kebudayaannya. Dengan demikian, bagaimanapun sederhananya peradaban suatu masyarakat, di dalamnya terjadi atau berlangsung suatu proses pendidikan. Karena itulah sering dinyatakan pendidikan telah ada sepanjang peradaban umat manusia. Pendidikan pada hakikatnya merupakan usaha manusia melestarikan hidupnya.

Pendidikan dalam arti mengajarkan segala sesuatu yang bermanfaat bagi kehidupan manusia, baik terhadap aktivitas jasmania, pikiran-pikirannya maupun terhadap ketajaman dan kelembutan hati nuraninya. ${ }^{7}$

Sementara Ki Hajar Dewantara mengartikan pendidikan sebagai upaya untuk memajukan budi pekerti, pikiran serta jasmani anak, agar dapat memajukan kesempurnaan hidup dan menghidupkan anak yang selaras dengan alam dan masyarakatnya.

\section{Hakikat Pendidikan Kewirausahaan.}

Secara sederhana arti wirausahawan (entrepreneur) adalah orang yang berjiwa berani mengambil risiko untuk membuka usaha dalam berbagai kesempatan. Berjiwa berani mengambil risiko artinya bermental mandiri dan berani memulai usaha, tanpa diliputi rasa takut atau cemas sekalipun dalam kondisi tidak pasti. Kegiatan wirausaha dapat dilakukan seorang diri atau berkelompok. ${ }^{8}$

Kewirausahaan merupakan mata pelajaran yang dapat diajarkan di sekolahsekolah dan telah bertumbuh sangat pesat. Transformasi pengetahuan kewirausahaan telah berkembang pada akhir-akhir ini. Demikian pula di negara kita pengetahuan kewirausahaan diajarkan di sekolah dasar, sekolah menengah, perguruan tinggi di berbagai kursus bisnis. Berikanlah para peserta didik penanaman sikap-sikap perilaku untuk membuka bisnis kemudian kita akan membuat mereka menjadi

\footnotetext{
${ }^{6}$ Suhartono, Suparlan. Filsafat Pendidikan. Cet. III, April(. Jogjakarta: Ar-Ruzz Media,
} 2008), hlm. 77

${ }^{7}$ Salahuddin Anas, "Filsafat Pendidikan (Bandung: CV Pustaka Setia. 2011), hlm. 19

${ }^{8}$ Muhammad Anwar, Pengantar Entrepreneurship Teori dan Aplikasiu, ( Jakarta:Prenada Media Group, 2014 ), hlm. 16 
seorang wirausaha yang berbakat ${ }^{9}$. Pendidikan kewirausahaan merupakan salah satu bentuk aplikasi kepedulian dunia pendidikan terhadap kemajuan bangsanya. Di dalam pendidikan kewirausahaan diperlihatkan di antaranya adalah nilai dan bentuk kerja untuk mencapai kesuksesan.

Ada dua pendapat tentang pengertian kewirausahaan, yaitu Peter F. Drucker mengatakan bahwa kewirausahaan merupakan kemampuan dalam menciptakan sesuatu yang baru dan berbeda. Pengertian ini mengandung maksud bahwa seorang entrepreneur adalah orang yang memiliki kemampuan untuk mencipta sesuatu yang baru, atau mampu menciptakan sesuatu yang berbeda dengan sesuatu yang sudah ada sebelumnya. Sementara itu, Zimmerer mengartikan kewirausahaan sebagai suatu proses penerapan kreativitas dan inovasi dalam memecahkan persoalan dan menemukan peluang untuk memperbaiki kehidupan. ${ }^{10}$

Dari kedua pendapat di atas dapat disimpulkan bahwa kewirausahaan merupakan suatu kemampuan dalam hal menciptakan kegiatan usaha. Seorang entrepreneur harus memiliki kemampuan yang kreatif dan inovatif dalam menemukan dan menciptakan berbagai ide.

Dari uraian konsep pendidikan kewirausahaan di atas, dapat disimpulkan bahwa kewirausahaan pada dasarnya terfokus pada upaya untuk mempelajari tentang nilai, kemampuan dan perilaku seseorang dalam berkreasi dan inovasi. Oleh sebab itu, objek studi kewirausahaan adalah nilai-nilai dan kemampuan seseorang yang diwujudkan dalam bentuk sikap.

\section{Internalisasi Pendidikan Kewirausahaan dalam Islam}

Keberhasilan seorang entrepreneur dalam Islam bersifat independen. Artinya keunggulan berpusat pada integritas pribadinya, bukan dari luar dirinya. Hal ini selain menimbulkan keandalan menghadapi tantangan, juga merupakan garansi tidak terjebak dalam praktik-praktik negatif yang bertentangan dengan peraturan, baikperaturan agama ataupun peraturan teknis negara tentang usaha. Integritas entrepreneur Muslim terlihat dalam sifat-sifatnya, antara lain: ${ }^{11}$

a. Takwa, tawakal, zikir, dan bersyukur

\footnotetext{
${ }^{9}$ Alma, Buchari, Entrepreneurship.( Bandung: Penerbit ALFABETA 2009), hlm.5

${ }^{10}$ Ibid, Alma, Buchari, Entrepreneurship, hlm. 8.

${ }^{11}$ Muhammad Anwar,Pengantar entrepreneurship teori dan aplikasi, hlm. 129-132
} 
b. Motivasinya bersifat vertical dan horizontal

c. Niat suci dan ibadah

d. Azam " bangun lebih pagi “

e. Selalu berusaha meningkatkan ilmu dan keterampilan

f. Jujur

g. Suka menyambung silaturahmi

h. Menunaikan zakat, infak, dan sedekah

i. Puasa, salat sunat, dan salat malam

j. Mengasuh anak yatim

Sebagai konsekuensi pentingnya kegiatan kewirausahaan, Islam menekankan pentingnya pembangunan dan penegakan budaya kewirausahaan dalam kehidupan setiap Muslim. Budaya kewirausahaan Muslim itu bersifat manusiawi dan religious, berbeda dengan budaya profesi lainnya yang tidak menjadikan pertimbangan agama sebagai landasan kerjanya. Dengan demikian, pendidikan entrepreneur Muslim akan memiliki sifat-sifat dasar yang mendorongnya untuk menjadi pribadi yang kreatif dan andal dalam menjalankan usahanya.

Jiwa entrepreneur seseorang bukanlah merupakan faktor keturunan, namun dapat dipelajari secara ilmiah dan ditumbuhkan bagi siapa pun juga. Pendidikan kewirausahaan dapat dilakukan apabila pendidik sudah memiliki jiwa entrepreneur yang tinggi. Yang penting dan yang utama dari pendidikan kewirausahaan adalah semangat untuk terus mencoba dan belajar dari pengalaman. " gagal itu biasa, berusaha terus itu yang luar biasa", mungkin seperti itulah gambaaran yang harus dikembangkan oleh manusia-manusia Indonesi8a agar tetap eksis dalam pertarungan bisnis yang semakin transparan dan terbuka.

\section{Kegiatan Kewirausahaan menurut Pandangan Islam}

Konsekuensi pentingnya kegiatan kewirausahaan, Islam menekankan pentingnya pembangunan dan penegakan budaya kewirausahaan dalam kehidupan setiap Muslim. Budaya kewirausahaan Muslim bersifat manusiawi dan religious, berbeda dengan budaya profesi lainnya yang tidak menjadikan pertimbangan agama sebagai landasan kerjanya. Dalam QS. At-Taubah (9): 105, Allah swt. Berfirman : 


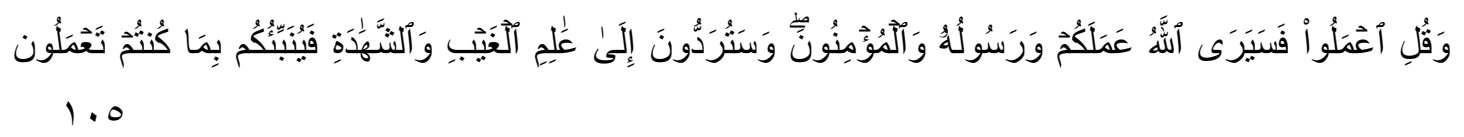

Terjemahnya:

“Dan Katakanlah: "Bekerjalah kamu, maka Allah dan Rasul-Nya serta orang-orang mukmin akan melihat pekerjaanmu itu, dan kamu akan dikembalikan kepada (Allah) Yang Mengetahui akan yang ghaib dan yang nyata, lalu diberitakan-Nya kepada kamu apa yang telah kamu kerjakan. ,'12

Oleh karena itu, apabila salat telah ditunaikan, maka bertebaranlah kamu di muka bumi dan carilah karunia ( rezeki) Allah. Dalam QS. Al-Jumuah (62) : 10 Allah berfirman:

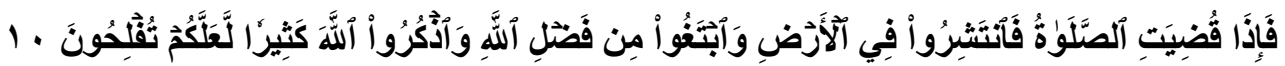

Terjemahnya:

'Apabila telah ditunaikan shalat, maka bertebaranlah kamu di muka bumi; dan carilah karunia Allah dan ingatlah Allah banyak-banyak supaya kamu beruntung. ",13

Berdasarkan beberapa definisi dan hasil penelitian terdahulu yang telah diungkapkan maka penelitian ini dapat disusun suatu kerangka konseptual tentang Internalisasi Pendidikan Kewirausahaan dalam Kurikulum di SMK Salafiya Syafi'iyah Randangan Gorontalo sebagai berikut.

\footnotetext{
${ }^{12}$ Departemen Agama RI, al-Quran dan Terjemahynya, ( Jakarta : Proyek Pengadaan Kitab Suci al-Quran, 2006 ), hlm. 200

${ }^{13}$ Ibid. hlm. 234
} 
Kerangka Konseptual Internalisasi Pendidikan Kewirausahaan Dalam

Kurikulum Di SMK Salafiya Syafi'iyah Randangan Gorontalo

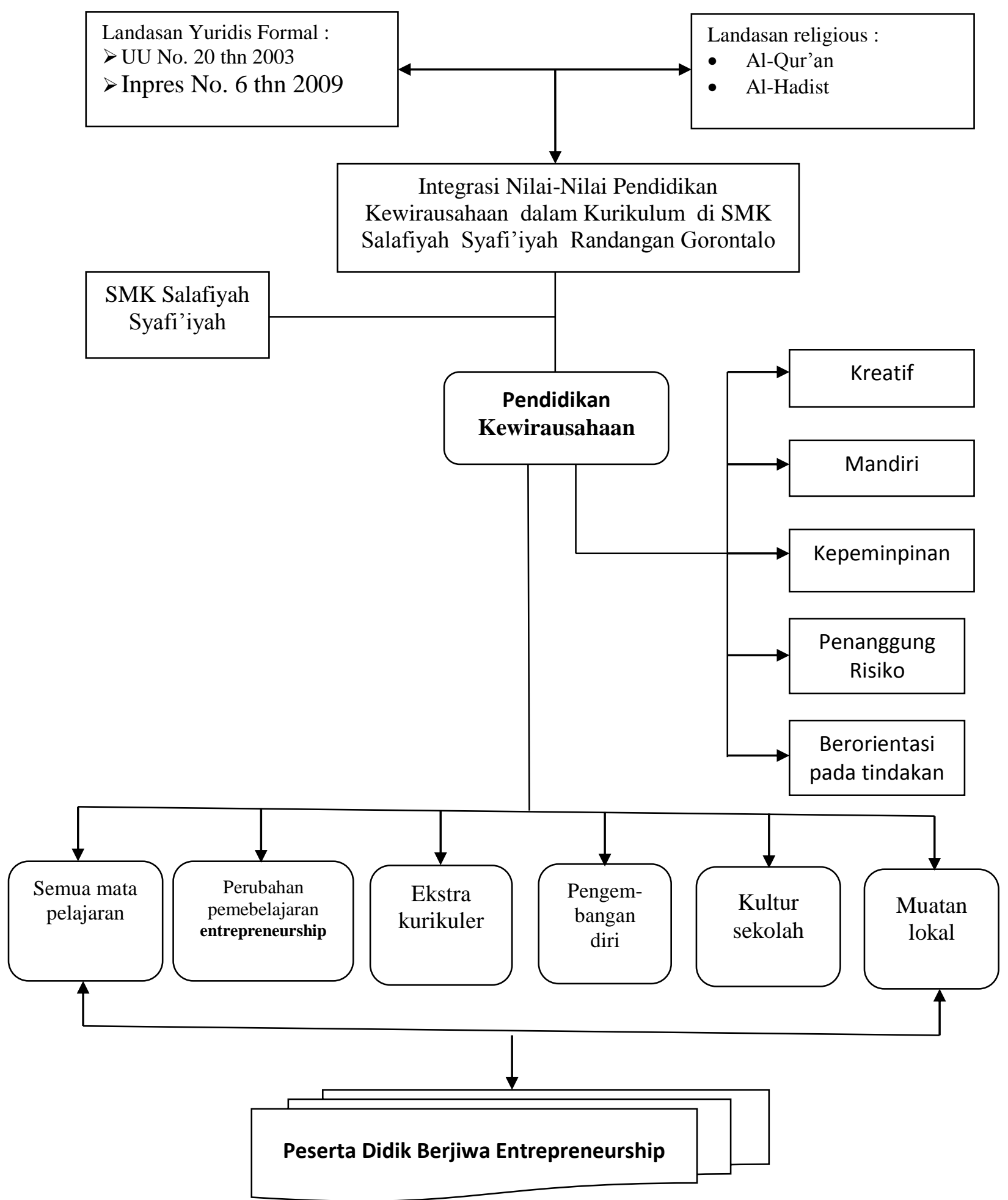

Gambar 1. Kerangka Konseptual 


\section{Hasil dan Pembahasan}

\section{A. Nilai-Nilai Pendidikan Kewirausahan}

Dalam proses belajar mengajar dibutuhkan suatu strategi untuk memudahkan pendidik maupun peserta didik dalam memahami dan mengintrepretasikan suatu ilmu khususnya dalam bidang pendidikan kewirausahaan yang diterapkan di sekolah SMK sesuai dengan kurikulum yang diharapkan dengan menginternalisasi lima nilai-nilai pokok kewirausahaan diantaranya nilai kreatif, mandiri, kepeminpinan, berani menanggun risiko dan beriorentasi pada tindakan dengan penjelasan sebagai berikut:

\section{Nilai Kreatif}

Hasil penelitian menunjukan bahwa pendidikan kewirausahaan di sekolah SMK Salafiyah syafi'iyah Randangan terintegrasi di dalam proses pembelajaran yang diinternalisasikan ke dalam nilai kreatif dan akan terbentuk karakter wirausaha dan pembiasaan nilai-nilai kewirausahaan ke dalam tingkah laku peserta didik sehari-hari melalui proses pembelajaran baik yang berlangsung di dalam kelas maupun di luar kelas pada semua mata pelajaran. Langkah internalisasi ini dapat dilihat pada saat guru menyampaikan materi, melalui metode pembelajaran maupun melalui sistem penilaian. Sekolah juga sebaiknya menyediakan alat-alat praktik yang lain,sehingga saat guru mengajarkan materi khusus praktik yang menggunakan alat tidak mengalami kesulitan, di luar dari yang telah siswa buat sendiri dari hasil kreativitasnya.

\section{Nilai Kemandirian}

Hasil penelitian menunjukan bawa dengan adanya nilai-nilai kemandirian yang ditanamkan pada diri peserta didik melalui pendidikan kewirausahaan di sekolah telah diinternalisasikan ke dalam semua mata pelajaran maka peserta didik dapat berperilaku mandiri dalam berpikir dan bertindak kreatif maupun inovatif dalam menyelesaikan berabagai masalah yang dihadapinya sebagaimana wawancara yang dilakukan kepada salah seorang guru disekolah salafiyah syafi'iyah Randangan yakni terdapat beberapa perubahan-perubahan yang sebelumnya sangat mengandalkan guru, namun dengan adanya nilai-nilai kemandirian tersebut setiap 
peserta didik sudah mampu berpikir dan bertindak kreatif dengan penuh inisiatif serta percaya diri untuk memperoleh kepuasan dari usahanya, seperti peserta didik dapat melakukan praktek langsung dengan menghasilkan suatu produk, dan kerajinan-kerajinan tangan lainnya. ${ }^{14}$

\section{Nilai Kepemimpinan}

Kepemimpinan merupakan suatu kemampuan seseorang untuk tidak bergantung dengan orang lain serta bertanggung jawab atas apa yang dilakukannya, dan hal tersebut sejalan dengan penjelasan dari informan yang merupakan salah seorang guru SMK Salafiyah safi'iyah Randangan Gorontalo pada saat peneliti mengadakan wawancara dan hasilnya sebagai berikut:

"Nilai kepemimpinan merupakan dorongan kepada peserta didik untukmemiliki karakter seorang pemimpin, jadi setiap peserta didik telah diajarkan untuk menjadi seorang pemimpin seperti hari senin peserta didik dapat melaksanakan upacara bendera, kegiatan pramuka dan di dalam kelas peserta didik selalu diajarkan membentuk kelompok diskusi sehingga dengan sendirinya peserta didik telah diajarkan tentang bagaimana menjadi seorang pemimpin". 15

Mengacu pada pernyataan informan di atas bahwa kepemimpinan merupakan faktor kunci bagi peserta didik dalam melakukan kegiatan -kegiatan sekolah dan mudah bergaul terhadap lingkungannya, mampu bekerja sama, mengkoordinir, dan mengoreksi maupun menegur teman yang dianggap keliru demikian pula datang di sekolah tepat pada waktunya, semangat kerja yang tinggi, dan jujur.

\section{Nilai Berani menanggung Risiko}

Berani menanggung risiko dalam pendidikan kewirausahaan yang diterapkan di sekolah khususnya di sekolah Salafiyah Syafi'iyah Randangan Gorontalo yang selanjutnya peneliti melakukan wawancara kepada salah seorang informan selaku wakil kepala sekolah bagian kurikulum dan hasil wawancaranya sebagai berikut:

"Berani menanggung risiko dalam hal ini peserta didik menyukai tugas yang menantang yang diberikan oleh guru dan berani menerima akibat dari tugas

\footnotetext{
${ }^{14}$ Agus Riyadi, guru, wawancara tanggal ,26 September 2015

${ }^{15}$ Solehuddin, Wawancara tanggal 26 September 2015
} 
tersebut, seperti berjualan produk olahan susu sapi dan kripik jagung dikalangan santri dan kegiatan bulanan pondok yakni kegiatan majelis taklim setiap malam jum'at yang di pondok pesantren salafiyah syafi'yah dan terkadang produk yang dijual tidak semuanya laku namu tetap berusaha keras untuk meningkatkan kualiats agar penjualan produk dapat ditingkatkan". ${ }^{16}$

Satu hal yang harus dimiliki peserta didik adalah suatu keberanian untuk mengambil keputusan yang siap dengan risikonya dan keyakinan yang kuat tentang keputusan apapun yang diambilnya pasti mengandung risiko yang harus ditanggung.

\section{Berorientasi pada tindakan}

Berorientasi pada tindakan merupakan suatu kemampuan seseorang untuk tidak bergantung dengan orang lain serta bertanggung jawab atas apa yang dilakukannya, dan hal tersebut sejalan dengan penjelasan dari informan yang merupakan salah seorang guru SMK Salafiyah safi'iyah Randangan Gorontalo pada saat peneliti mengadakan wawancara dan hasilnya sebagai berikut

"Memberikan kesempatan kepada peserta didik untuk menerapkan gagasannya seperti yang telah dijelaskan diatas bahwa saat anak diberi tugas dan anak tersebut senang melakukannya, dan peserta didik dapat mewujudkan gagasan dengan tindakan, misalnya diminta untuk membuat alat-alat peraga dan mereka langsung mewujudkannya dengan mencari bahan-bahannya". ${ }^{17}$

Peserta didik harus menpelajari bagaimana menghadapi risiko, ketidakpastian, dan keterbatasan dalam setiap masalah yang dihadapi dan bagaimana mengambil suatu tindakan atau keputusan dengan cepat agar dapat menggunakan kesempatan sebaik-baiknya seperti seorang entrepreneur yang ingin maju dalam bisnisnya, maka harus dapat mengandalkan intuisi, ide-ide yang penuh kreatif dan inovatif.

\section{B. Faktor Pendukung Internalisasi Nilai-Nilai Pendidikan Kewirausahaan}

\footnotetext{
${ }^{16}$ Agus Riyadi, wakil kepala sekolah bagian kurikulum, wawancara tanggal, 26 September 2015

${ }^{17}$ Gunawan, guru, wawancara tanggal, 26 September 2015
} 
Dalam proses pembelajaran di kelas guru membutuhkan pendukung berupa media sebagai sumber belajar. Adapun media yang digunakan diantaranya adalah: white board, LCD, buku paket, internet dan lain sebagainya. Sedangkan untuk sumber materi praktikan menggunakan beberapa buku acuan yang tersedia di perpustakaan, buku pegangan guru, kurikulum dan dari internet serta laboratorium tempat praktik. Sesuai dengan hasil pengamatan penulis di lapangan, bahwa di SMK Salafiyah Syafi'iyah Randangan Gorontalo semua fasilitas ini di gunakan oleh guru sebagai alat pendukung pada saat proses pembelajaran berlangsung. Selain itu faktor pendukung penginternalisasian nilai-nilai kewirausahaan adalah semangat belajar yang tinggi dari peserta didik, ruang belajar yang nyaman, suasana belajar yang kondusif, metode pembelajaran yang tepat, media atau alat belajar yang lengkap dan berfungsi baik, pengajar yang pakar dibidangnya, dan adanya keteladanan yang baik dan berperilaku oleh para pendidik. Dengan adanya pendukung tersebut tentunya akan mendukung internalisasi nilai-nilai pendidikan kewirausahaan dengan tersedianya fasilitas yang dibutuhkan oleh guru dalam proses pembelajaran, berarti penerapan internalisasi nilai-nilai pendidikan kewirausahaan di sekolah dapat tercapai dengan baik dan benar sesuai harapan dan tujuan diberlakukannya sebuah kurikulum.

\section{Faktor Penghambat Internalisasi Nilai-Nilai Pendidikan Kewirausahaan}

Pendidikan kewirausahaan di sekolah jika terinternalisasi di setiap mata pelajaran maka perlu dikembangkan, dieksplisitkan, dikaitkan dengan konteks kehidupan sehari-hari. Dengan demikian, pembelajaran yang berwawasan pendidikan kewirausahaan tidak hanya pada tataran kognitif, tetapi menyentuh pada internalisasi, dan pengamalan nyata dalam kehidupan peserta didik sehari-hari di masyarakat. ${ }^{18}$

Hal tersebut sebagaimana yang di jelaskan oleh informan secara singkat saat diwawancarai, bahwa factor penghambat yang sering dihadapi dalam internalisasi nilai-nilai pendidikan kewirausahaan adalah sebagai berikut:

18 Budi Wahyono,." Permasalahan Pendidikan Entrepreneurship di Indonesia dan Bagaimana Solusinya", dalam www.pendidikanekonomi.com, diakses tanggal 26 Desember 2015 
"Seorang pengajar butuh kesabaran dalam menyampaikan materi karena tingkat pemahaman peserta didik berbeda-beda sehingga materi yang disampaikan harus dilakukan secara berulang-ulan akibatnya materi seringkali tertinggal dari hal yang telah direncanakan". 19

Dengan tingkat pemahaman peserta didik yang berbeda-beda untuk memahami pelajaran maka seorang guru dalam menyajikan materi perlu adanya keterampilan atau kompetensi untuk memahami secara khusus setiap peserta didik dalam mentransfer materi karena setiap pesarta didik dalam memahami setiap materi yang diberikan ada yang cepat menerima materi yang disampaikan oleh guru dan adapula yang lambat sehingga seorang guru dibutuhkan kesabaran dalam proses pembelajaran.

Secara singkat hal lain juga disampaikan informan selaku guru disaat peneliti menemui di ruang kepala sekolah bahwa hambatan sering muncul dalam internalisasi nilai-nilai pendidikan kewirausahaan di sekolah khususnya di SMK Salafiyah Syafi'iyah sebagai berikut:

Dalam internalisasi nilai-nilai pendidikan kewirausahaan di sekolah yang menjadi penghambatnya adalah padatnya jam mengajar yang dibebankan kepada guru, kelas yang tidak sebanding dengan jumlah siswa, ruangan praktek terbatas dan keterbatasan alat penunjang mata pelajaran serta belum ada mitra kerja dari luar sekolah. ${ }^{20}$

Bahwa faktor penghambat selalu ada dalam setiap kegiatan seperti padatnya jam mengajar yang diampuh oleh seorang guru mengangkibatkan guru tidak mampu mengajar secara maksimal sehingga peserta didik tidak dapat menerima materi dengan baik, hal tersebut merupakan hambatan dalam proses pembelajaran di sekolah khususnya dalam menginternalisasi nilai-nilai pendidikan kewirausahaan di sekolah perlu adanya guru yang profesional, demikian pula faktor penghambat dalam menerapkan internalisasi nilai -nilai kewirausahaan di sekolah adalah fasilitas atau ruangan untuk melakukan praktik kewirausahaan sangat terbatas dan mitra dari pihak lain untuk mengembangkan usaha kreativitas dan produktivitas siswa tidak dapat dikembangkan tetapi hanya sebatas praktik.

\footnotetext{
${ }^{19}$ Siti maria Ulfa, guru, wawancara pada tanggal 26 September 2015

${ }^{20}$ Agus Riadi, Guru, wawancara pada tanggal 26 September 2015
} 


\section{Kesimpulan}

Kecenderungan sikap atau nilai-nilai kewirausahaan yang dimiliki siswa berdasarkan hasil tes menunjukkan angka yang relatif belum optimal hal ini mengindikasikan bahwa sikap kewirausahaan siswa belum terbentuk dengan baik, hasil analisis kurikulum yang digunakan oleh SMK Salafiyah Syafi'iyah Randangan menunjukkan bahwa kompetensi yang ingin dicapai dengan sajian materi pelajaran kewirausahaan, menunjukkan masih sangat minim materi yang diarahkan pada pembentukan sikap/nilai namun lebih kepenambahan wawasan kewirausahaan dan demikian pula bahwa keterampilan mengelola bisnis, serta bahan ajar yang dipergunakan sebagai referensi guru untuk mata pelajaran kewirausahaan sangat terbatas, hal tersebut menimbulkan keterbatasan alokasi waktu sebab, SMK Salafiyah Syafi'iyah Randangan belum memiliki sarana dan fasilitas yang memadai terutama dalam membuat IB ( Inseminasi Buatan).

Internalisasi nilai-nilai kewirausahaan ke semua mata pelajaran telah diterapkan namun belum maksimal, terbukti sudah dimasukkannya nilai-nilai tersebut ke dalam perencanaan pembelajaran seperti memasukkan nilai yang di internalisasi ke dalam silabus ataupun RPP, begitupula dalam pelaksanaan pembelajaran dengan segala keterbatasan guru yang tidak berlatar belakang pendidikan kewirausahaan sehingga sedikit sulit dalam menentukan nilai yang akan diinternalisasikan dengan materi yang diajarkan, Selain itu evaluasi pembelajaran yang dilaksanakan oleh guru masih sederhana yaitu dalam hal nilai setelah pembelajaran ada evaluasi yang diberikan kepada peserta didik hanya berbentuk nilai yang telah di tetapkan sendiri oleh setiap guru mata pelajaran yang terangkum dalam absen guru tanpa membuat instrumen atau desain evaluasi seperti pemberian tugas dengan essai dan pilihan ganda yang belum mengacu pada standar penilaian diantaranya dengan membuat instrument.

Adapun yang manjadi kendala dalam internalisasi nilai-nilai pendidikan kewirausahaan di SMK Salafiyah Syafi'iyah Randangan yaitu keterlambatan peserta didik di ruang belajar, tingkat pemahaman peserta didik yang berbeda-beda, guru yang tidak sesuai dengan latar belakang pendidikan, metode pembelajaran yang dilakukan guru yang tidak tepat, serta tidak bervariasi yang mengakibatkan peserta didik jenuh saat pembelajaran, ketersediaan sarana dan prasarana praktik yang minim, serta keterbatasan modal dari sekolah dalam mendukung praktik siswa. 


\section{DAFTAR PUSTAKA}

Alma, Buchari, Kewirausahaan, Bandung : Penerbit Alfabeta, 2009.

Anas, Salahuddin, "Filsafat Pendidikan, Bandung: CV Pustaka Setia, 2011.

Anwar, Muhammad, Pengantar Kewirausahaan Teori dan Aplikasi, Jakarta: Prenadamedia Group, 2014.

Apidana, Gregrorius Fajar,, Faktor-Faktor Penghambat, Pendukung, Penentu Kegagalan dan Keberhasilan Entrepreneurship Dalam Dunia Konstruksi, tesis. Yokyakarta: Program Studi Magister Teknik Sipil Universitas Atma Jaya, 2012

Arikunto, Suharsimi, Prosedur Penelitian; Suatu Pendekatan Praktek. Jakarta: Rineka Cipta, 1999.

Astamoen, Moko P., Entrepreneurship dalam Perspektif Kondisi Bangsa Indonesia, Bandung: Alfabeta, 2005.

Badudu, Kamus Umum Bahasa Indonesia, Jakatra: Pustaka Sinar Harapan, 1994.

Basrowi, Kewirausahaan untuk Perguruan Tinggi, Bogor: Ghalia Indonesia, 2011.

Bisri, Cik Hasan, Penuntutan Penyusunan Rencana Penelitian, Jakarta: PT Rajagrafindo Persada, 2003)

Bogdan dan Biklen, Dasar-dasar Penelitian Kualitatif, 2001.

Bogdan, Robert dan Steven J. Tailor, Dasar-Dasar Penelitian Kualitatif. terjemahan A. Khosin Afandi, Surabaya: Usaha Nasional, 1993.

Ciputra, dalam Rianto Nugroho,Memahami Latar Belakang Pemikiran Entreprenership Ciputra, Jakarta: PT Elex Media Komputindo, 2010.

Danim, Sudarwam, Menjadi Peneliti Kualitatif. Bandung: Pustaka Setia, 2002

Daryanto, Kewirausahaan, Yokyakarta: Gava Media, 2013

Departemen Agama RI, al-Quran dan Terjemahnya, Jakarta : Proyek Pengadaan Kitab Suci al-Quran, 2006.

Engkoswara, Instructional Strategy of Civic Education at Certain School level, 1999.

Fajri, Em Zul, dan Ratu Aprillia Senja., Kamus Lengkap Bahasa Indonesia, Yokyakarta: Publisher, 2005. 
Fatimah, Enung, Psikologi Perkembangan: Perkembangan Peserta Didik, Bandung : Pustaka Setia, 2006.

Gay,L.R, Educational Research: Competencies for Analysis and Applications, Toronto: Merril Pubhlishing Company, 1987.

Hatta ,Ahmad, Tafsir Quran Per Kata, Jakarta: Maghfirah Pustaka, 2011.

Halim, Abdul, Model Pengembangan Kewirausahaan Sekolah Menengah Kejuruan (Smk) Dalam Menciptakan Kemandirian Sekolah, Jurnal, Riptek, Vol.4, No.1, Tahun 2010

Hasanah ,Muwahidah Nur," Implementasi Pendidikan Kewirausahaan dalam Perspektif Islam Di Smk Muhammadiyah 2 Ngawi Jawa Timur",Tesis, Program Pascasarjana Universitas Muhammadiyah Surakarta, 2013/2014

Kasmir, Kewirausahaan, Ed.Revisi, Jakarta: Rajawali Pers, 2014.

Kepmendiknas. Bahan Pelatihan Penguatan Metodologi Pembelajaran Berdasarkan Nilai-nilai Budaya untuk Membentuk Daya saing bangsa. Pendidikan Kewirausahaan. Jakarta: Pusat Kurikulum Muslimin Ibrahim, dkk.. Pembelajaran Kooperatif(. Surabaya: University Press 2010)

khumairo, Aisyah, Bimbingan Karir DalammMenumbuhkan Perilaku Kewirausahaan Santri Di Pondok Pesantren Entrepreneur Ad-Dhuha Bantul Yogyakarta, Tesis, UIN Sunan KaliJaga Yogyakarta, 2015

Lincoln, Yvonna S dan Egon Guba, Naturalistic Inquiry, Beverly Hills: SAGE Publications,Inc,1990.

Madyo, Ekosusilo, Dasar-Dasar pendidikan, Semarang: Efhar Offset Semarang, 1990.

Masruri. 2014. Analisis Efektifitas Program Nasional Pemberdayaan Masyarakat Mandiri Perkotaan (PNPM-MP) (Studi Kasus Pada Kecamatan Bunyu Kabupaten Bulungan tahun 2010). Governance and Public Policy, vol. 1 (1): 53-76

Marja, Upaya Pembelajaran Nilai Kewirausahaan dalam Menumbuhkembangkan Kemandirian Nelayan, Tesis: IKIP Bandung, 1998.

Mathew B.Miles and A.Michael Huberman, Qualitative Data Analysis. London : Sage Publication,Inc.

Miles \& Huberman, Analisis Data Kualitatif. Jakarta: UI-Press, 1992.

Muhajir, Noeng, Metodologi Penelitian Kualitatif. Ed.III; Cet. VII; Yogyakarta: Rake Sarasin, 1996.

Munawaroh, Siti, Pendayagunaan Kewirausahaan Di Smk Satya Karya Karanganyar, Tesis, Surakarta: Program Magister Manajemen Pendidikan Pascasarjana UMS,2014 
Muliani, Endang, Jurnal Ekonomi dan Pendidikan, vol. 8 Nomor 1, April 2011

Mulyadi, Implementasi Nilai Manajemen Qalbu di Pondok Pesantren Dar Al Tawhid, Bandung: Tesis SPS UPI, 2007.

Moleong, Lexy J, Metodologi Penelitian Kualitatif; Edisi Revisi, Bandung : PT Remaja Rosdakarya, 2014.

Nasution, Bahder Johan, Metode Penelitian Ilmu Hukum, Bandung: CV Mandar Maju, 2008.

Nata , Abuddin, Kapita Selekta Pendidikan Islam, Jakarta: PT. Raja Grapindo Persada, 2012

Nugroho, Riant, Memahami Latar Belakang Pemikiran Entrepreneyurship Ciputra Jakarta: PT Elex Media Komputindo,2010.

Nurfitria, Pipiet, "Pendidikan Kewirausahaan Perspektif Behaviorisme dalam Membentuk Jiwa Entrepreneur Siswa SMK 1 Cirebon" Tesis, Cirebon: Program Pasca Sarjana Institut Agama Islam Negeri, Syekh Nurjati, 2012.

Prawirokusuma, Soeharto, dalam Muhammad Anwar, Pengantar Kewirausahaan Teori dan Aplikasi, Jakarta: Prenadamedia Group, 2014.

Saifullah, Metode Penelitian, Malang: Fakultas Syariah, 2006.

Singaribun, Masri dan Sofyan, Metode dalam Penelitian Survey, Jakarta: LP3ES, 1987.

Siswanto, Ibnu, Faktor Pendukung Dan Penghambat Pelaksanaan Unit Produksi, Jurnal Penelitian dan Pengabdian Kepada Masyarakat (PPKM) LP3M-PB UNSIQ Wonosobo Volume 2 No 2 Mei 2015 ISSN 2354-869X

Soetopo, Hendyat, Pendidikan dan Pembelajaran, Teori, permasalahan, dan Praktek Malang: UMM Press. 2005.

Soekanto, Soerjono, Pengantar Penelitian Hukum, Jakarta: UI-Press, 1986.

Spadley, James P, Participation Observation, New York: Holt, Rinerhart and Winston, 1990.

Strauss, Anslem and Juliet Corbin, Basis Of Qualitative Research:Grounded Theory Procedure and Techniques, London: Sage Publications, 1990.

Suhartono, Suparlan. Filsafat Pendidikan. Cet. III, April, Jogjakarta: Ar-Ruzz Media, 2008.

Sugiyono, Metode Penelitian Pendidikan Kuantitatif, Kualitatif dan $R \& D$. 
Bandung : Alfabeta. 2006.

Sunarto, Ahmad, Mutiara Hadits Qudsi. 1 Januari, Surabaya: Karya Agung, 2007.

Susilo, Muhammad Joko, Kurikulum Tingkat Satuan Pendidikan Manajemen Pelaksanaan dan Kesiapan Sekolah Menyongsongnya, Yogyakarta : Pustaka Pelajar, 2007.

Undang-Undang Sisdiknas, Yokyakarta: Pustaka Pelajar, 2005.

Usman, Husaini, Peran Baru Administrasi Pendidikan dari Sentralistik Menuju Sistem Desentralistik, Artikel dalam Jurnal Ilmu Pendidikan, Jakarta: Pebruari 2001, Jilid 8 No.1

Usman, Husaini \& Nuryadin Eko Raharjo, "Model Pendidikan Karakter Kewirausahaan di Sekolah Menengah Kejuruan”Jurnal Pendidikan Teknologi dan Kejuruan,Vol.21 Nomor 2,Oktober 2012.

Verawati, Yenny, Analisis Efektivitas Keberlangsungan Modal Usaha Simpan Pinjam Perempuan PNPM Mandiri Perdesaan Di Kecamatan Mengwi Kabupaten Badung",Tesis, program Pascasarjana Universitas Udayana Denpasar,2014.

Wiratno, Siswo,pelaksanaan pendidikan kewirausahaan, Jurnal Pendidikan dan Kebudayaan, Vol. 18, Nomor 4, Desember 2012

Winarno, Agung, Pendidikan Kewirausahaan Smk Dengan K-13: Persepektif Guru Dan Sekolah, Seminar Nasional Ekonomi Manajemen Dan Akuntansi (Snema) Fakultas Ekonomi Universitas Negeri PadangSnema-2015.

Yulianingsih, Wiwiw, "Efektifitas Program Pendidikan Kewirausahaan Masyarakat melalui Model Enam Fitur Inti Sebagai Upaya Menumbuhkan Wirausahadi Wilayah Binaan Upt Skb Cerme Kabupaten Gresik”, Tesisi Fakultas Ilmu Pendidikan Universitas Negeri, Surabaya, 2014.

Zubaedi, Isu-Isu Baru dalam Diskursus Filsafat Pendidikan Islam dan Kapita selekta Pendidikan islam,, Yogyakarta: Pustaka Pelajar, 2012. 